\title{
Occupational Stress and Work-Life Balance: A Study of Female Faculties of Central Universities in Delhi, India
}

\author{
Asma Zaheer ${ }^{1}$, Jamid UI Islam², Nahid Darakhshan ${ }^{3}$ \\ ${ }^{1}$ Faculty of Economics and Administration, King Abdulaziz University, Jeddah, Saudi Arabia \\ ${ }^{2}$ Indian Institute of Technology Roorkee, Roorkee, India \\ ${ }^{3}$ Guest Faculty, Centre for Management Studies, Jamia Millia Islamia, New Delhi, India
}

Email address:

dr_asmazaheer@yahoo.com (A. Zaheer),jammicms.kmr@gmail.com (J. Ul Islam), nahid.darakhshan@gmail.com (N. Darakhshan)

\section{To cite this article:}

Asma Zaheer, Jamid U1 Islam, Nahid Darakhshan. Occupational Stress and Work-Life Balance: A Study of Female Faculties of Central Universities in Delhi, India. Journal of Human Resource Management. Vol. 4, No. 1, 2016, pp. 1-5. doi: 10.11648/j.jhrm.20160401.11

\begin{abstract}
This study specifically investigates the degree of and the relationship between occupational stress and work-life balance amid female faculties in central universities of Delhi, India. The study is based on primary data collected from 120 female faculties from two central universities in Delhi, India. The data are analyzed using various statistical tools and methods. The results of the study reveal that there exists a moderate-level of occupational stress and moderate-level of work-life balance amid female faculties in central universities of Delhi, India. The results of the study further reveal that there is a strong negative relationship between Occupational Stress and Work-Life Balance. This study can prove to be of great help to the management of educational set-up to increase the level of work-life balance and decrease the level of occupational stress among their faculty members; so as to create a work environment that everyone feels proud to be the part of. This, in turn, will increase the organizational efficiency and effectiveness in academic set- ups.
\end{abstract}

Keywords: Occupational Stress, Work-Life Balance, Female Faculties, India

\section{Introduction}

Time has changed from men being the sole bread-earner to the world where both men and women equally share the responsibility of family-life and society. Women have shown their presence in every thought. From sports to aeronautics, from politics to engineering, from medical professions to academics, women have contributed significantly in almost every field. Women working in universities; is just one single area of our focus. On one hand, working in universities as faculty proves out to be a life sustaining income for women, but on the other hand, it also exerts its own pressures on them. Working life has changed a lot during the last few decades causing increased occupational stress and work-life imbalance for female faculties at educational institutes. Work Life Balance of women employee is viewed as an important domain of discussion among researchers in the last few decades.

According to Hagen R (2002), "universities are the largest 'knowledge-based' institution in the region; hence they are urged by the industry and policy makers to transform their traditional roles of teaching and research by adding an additional pivotal role in economic regional development".

However, extra demands on female academic employees could contribute to their occupational stress and work-life imbalance. This can ultimately give rise to negative consequences for achieving the organizational goals and meeting the needs of the employees working with them. Today the cry of occupational stress is heard from all the nooks and corners of the world and occupational stress and work-life balance have become major concerns for working women as well as the organizations.

Thus, an understanding of occupational stress and worklife balance of females in higher education sector is of great importance for educational set-ups as well as the nation at large so that female faculties are encouraged to provide their efforts to build a civilized nation. Work-life balance and job stress go parallel to each other. What seems to be important in this connection is the importance employees give on balancing their lives and the effectiveness of workplace practices and policies in supporting them to achieve such a goal (Ross \& Vasantha, 2014). According to Peeters, Montgomery, Bakker and Schaufeli (2005), pressures from 
the family and job domains are mostly incompatible, that give rise to imbalance. Therefore, the discussion of work life balance as well as its implications is a crucial issue and needs to be investigated because more women are working in the Indian society.

This study attempts to investigate the occupational stress and work-life balance amid female faculties in central universities of Delhi, India. The next section provides the literature review of the constructs under study followed by the data analysis and discussion.

\section{Literature Review}

Occupational Stress defined by Leka, Griffiths and Cox (2004) is "the response people may have when presented with work demands and pressures that are not matched to their knowledge and abilities and which challenge their ability to cope". In literature, Job stress has been conceptualized as a state in which job related factors interact with a person to change his/her physiological or psychological conditions so much so that the person is made to deviate from the normal functioning (Beehr and Newman, 1978). Comish \& Swindle (1994) states it as a mental as well as physical condition that affects an individual's personal health, effectiveness, productivity, and quality of work.

Work-life Balance according to Mc Auley F et al (2003) is described as "a competition for both time and energy between the different roles filled by an individual". Vijaya Mani (2013) has identified some of the crucial factors affecting the work life balance of female professionals in India, which include gender discrimination, role conflict, organizational politics, lack of recognition, elderly and children care issues, issues in time management, quality of health, and lack of social support. Rout, Lewis and Kagan (1999) reveal that women professors experience a due amount of pressure in the morning times before going out to work and in the evening times after work, to do all the extra work that is important for the family.

Work-life Conflict as defined by Higgins, Duxbury \& Lyons (2001) is a "form of inter-role conflict in which work and family demands are mutually incompatible, meeting demands of both the domains is difficult".

One cannot neglect work-life balance as a crucial issue for a working person not because of its benefits only but also because of its ill consequences that could generate with work- life imbalance.

O' Laughlin et al (2005) have identified multiple role demands of academic staffs within the work setting, e.g., teaching, consultation, research, and supervising research scholars, as key factors contributing to job stress. Ironically, academicians have keenly researched other professional groups, but there is a dearth of studies in their own context. Hence there is a significant need to focus on the unfocused sector. Cox et al (1978) specified in their research on stress and well-being of school teachers that more than 60 per cent of teachers considered working as the prime cause of stress in their lives. In another study, Kyriacou (1980) reveals that teachers, when compared to other professionals, experience a greater level of stress. The grounds for the stress in such profession are numerous. Repetti, R.L. (1992) and Repetti, R.L. \& Wood, J. (1997) suggest that women teachers perceive more stress than men and cope differently with it. One finding by American Psychological Association suggests that even though women are more likely to address physical symptoms connected with stress, they do a better job in getting connecting with others in their lives and, most of the times, these connections turn out to be effective stress management strategies for them. Grecu et al. (2014) highlights that specific personality characteristics and a person's coping mechanisms play a predictor role in the stress process. Colbeck et al. (2006) revealed that male academicians of universities spent relatively more time on work and lesser time on personal activities than female academicians. Women do not see work and family roles as mutually exclusive. Arnold J et al (1991) states that "an occupational stress can be caused by too much or too little work, time pressure and deadlines, fatigue from physical strains of work environment, excessive travelling, long hours, having to cope with changes in work". Chand and Monga (2007) while studying the correlates of burnout and job stress among teachers in India found that minimum job stress was reported by the assistant professors and maximum by professors. Moreover, work life balance was found to influence the performance of Italian female workers (Poggesi, 2015).

\section{Objectives}

Some circumstantial objectives of current study are:

I To investigate the level of Occupational Stress among female faculties in central universities of Delhi.

II To investigate the level of work-life balance among female faculties in central universities of Delhi.

III To assess the relationship between occupational stress and work-life balance amid female faculties in central universities of Delhi.

\section{Research Methodology}

For this study, 2 Public universities (Jamia Millia Islamia and Delhi University) were selected in Delhi, India. Various faculties (like Faculty of Social Science, Political Science and Humanities and Languages) and centers (like Centre for Management Studies and Centre for West Asian Studies) of Jamia Millia Islamia and several colleges (like Kamlabai College, Bhagat Singh College, Jesus and Marry College and Zakir Husain College) of Delhi University were been chosen for survey. These faculties, centers and colleges were selected for data collection using purposive sampling.

The respondents of this study are the randomly selected female faculty members from different faculties, centers and colleges of the two universities.

The sample size selected was 120 respondents, 60 from each university. Self-administered questionnaires were given 
to the respondents. Out of 120 distributed questionnaires, 90 completed questionnaires were returned, resulting in a response rate of $75 \%$.

The research instrument used to collect data for this study is the self-administered questionnaire. This questionnaire included different structured scales for Occupational stress and Work-Life balance along with a section that includes questions related to biographical information. Various statistical techniques and methods such as descriptive statistics and correlation have been used to analyze the data.

\section{Data Analysis and Interpretation}

Frequency Distribution of Biographical Information of the respondents is given below in Table-1, 2, 3, and 4.

Table 1. Frequency Distribution of Age of Respondents.

\begin{tabular}{lll}
\hline Age & No. of respondents in the sample & Percentage \\
\hline Less than 25 & 6 & 6.66 \\
$26-35$ & 24 & 26.66 \\
$36-45$ & 33 & 36.66 \\
$46-55$ & 16 & 17.77 \\
$56-65$ & 6 & 6.66 \\
66 and Above & 5 & 5.55 \\
Total & 90 & 100 \\
\hline
\end{tabular}

Table 2. Frequency Distribution of Educational Qualification of Respondents.

\begin{tabular}{lll}
\hline $\begin{array}{l}\text { Educational } \\
\text { Qualification }\end{array}$ & $\begin{array}{l}\text { No. of respondents in the } \\
\text { sample }\end{array}$ & Percentage \\
\hline Masters & 35 & 38.88 \\
Masters and above & 55 & 61.11 \\
Total & 90 & 100 \\
\hline
\end{tabular}

Table 3. Frequency Distribution of Years of Lecturing Experience of Respondents.

\begin{tabular}{lll}
\hline $\begin{array}{l}\text { Lecturing Experience in } \\
\text { years }\end{array}$ & $\begin{array}{l}\text { No. of respondents in the } \\
\text { sample }\end{array}$ & Percentage \\
\hline 0-5 years & 20 & 22.22 \\
5-10 years & 38 & 42.22 \\
10-15 years & 18 & 20 \\
15 years and Above & 14 & 15.55 \\
Total & 90 & 100 \\
\hline
\end{tabular}

Table 4. Frequency Distribution of Marital Status of Respondents.

\begin{tabular}{lll}
\hline Marital Status & No. of respondents in the sample & Percentage \\
\hline Single & 30 & 33.33 \\
Married & 45 & 50 \\
Divorced & 9 & 10 \\
Widowed & 6 & 6.66 \\
Total & 90 & 100 \\
\hline
\end{tabular}

Level of Occupational stress: The mean value of the scores obtained from individual cases can range from 30 to 150 . Low score signifies low level of work- stress and vice versa. Hence, mean score below 90(median) will represent low level of occupational stress and mean score above 90 will signifies high level of occupational stress, as shown in Table-5.

Level of Work-Life Balance: The mean value of the scores obtained from individual cases can range from 26 to 130 . Here, the low score signifies high level of work-life balance and vice versa. Hence, mean score below 78(median) will represent high level of work-life balance or low level of work-life imbalance and mean value above 78 will signifies low level of work-life balance or high level of work-life imbalance, as shown in Table-5.

Table 5. Mean, Median, Mode, and Standard Deviation of Occupational Stress and Work-Life Imbalance.

\begin{tabular}{lll}
\hline Items & Occupational Stress & Work-Life Imbalance \\
\hline Mean & 82.55 & 74.23 \\
Median & 81 & 71 \\
Mode & 81 & 72 \\
Standard Deviation & 13.225 & 13.0883 \\
Count & 90 & 90 \\
\hline
\end{tabular}

From the data table above, it can be drawn that the mean value for Occupational stress is 82.55 i. e. it lies close to the median value (90). Thus the occupational stress among the female faculty of central universities of Delhi is neither too high nor too low but is moderate.

The mean value of Work-Life Imbalance is 74.23 which is again close to the median value of 78 . Thus, the female faculty of central universities of Delhi are having a moderate level of work-life imbalance or Work-Life Balance.

Correlation analysis was done to understand the relationship between occupational stress and work-Life Imbalance, as depicted in Table-6.

Table 6. Correlation between occupational stress and work-Life Imbalance.

\begin{tabular}{llll}
\hline & & $\begin{array}{l}\text { Occupational } \\
\text { Stress }\end{array}$ & $\begin{array}{l}\text { work-Life } \\
\text { Imbalance }\end{array}$ \\
\hline $\begin{array}{l}\text { Occupational } \\
\text { Stress }\end{array}$ & $\begin{array}{l}\text { Pearson } \\
\text { Correlation }\end{array}$ & 1 & 0.73 \\
& Sig.(2-tailed) & & 0.01 \\
& $\mathrm{~N}$ & 90 & 90 \\
work-Life & Pearson & 0.73 & 1 \\
Imbalance & Correlation & 0.01 & \\
& Sig.(2-tailed) & 90 & 90 \\
\hline
\end{tabular}

From the above table, it is clear that there is a strong positive relationship between occupational stress and worklife imbalance of women faculties of central universities of Delhi. In other words, a strong negative relationship exists between occupational stress and work-life balance. That is, changes in one variable are strongly correlated with changes in other as the coefficient value is 0.73 .

The Sig. (2-Tailed) value in the case is 0.01 . This value is less than. 05. Because of this, it can be concluded that there is a statistically significant correlation between the level of occupational stress and the level of work-life imbalance. 


\section{Discussion}

The motive of this study was to investigate the occupational stress and work-life balance amid female faculties in central universities of Delhi, India. The study was also conducted to determine the relationship between occupational stress and work-life balance amid the female faculties.

The results of the study reveal that there is a moderate level of occupational stress among the female faculty. The finding is consistent with the research conducted by Ali Raza (2012) which indicates that there is a moderate level of stress perceived by university teachers of Punjab and stress is not a big problem in the environment of higher education institutions. But the finding is inconsistent with a number of earlier studies such as Kyriacou (1980) revealed that when compared to people in other professions, teachers do experience a greater level of stress. Cox et al (1978) reported that more than 60 per cent of teachers considered working as the main source of stress in their lives.

But it should be kept in mind that no study has taken women faculties of Jamia Millia Islamia and Delhi University as sample to conduct such research. Hence, though the organizational settings could be similar but not same. Thus, the finding holds good.

The correlation analysis identified a strong positive relationship between occupational stress and work life imbalance of female faculty in central universities of Delhi. Hence, changes in one variable may be used to make changes in another.

The implication of this empirical article is notable since little research prevails concerning occupational stress and work life balance among women faculties in higher educational institutions in Delhi. This information may help in framing appropriate policies and practices within the educational institutions.

\section{References}

[1] American Psychological Association: Stress and Gender. http://www.apa.org/news/press/releases/stress/genderstress.pdf.

[2] Arnold J et al (1991), Understanding Human Behavior at the Work Place, Work Psychology London Pitman Publishing, pp.42-43.

[3] Beehr, T. A., \& Newman, J. (1978). Job Stress, Employee Health and Organizational Effectiveness: A Facet Analysis Model and Literature Review. Personnel Psychology, 31, pp.655-669.

[4] Chand, P., \& Monga, O. P. (2007). Correlates of job stress and burnout. Journal of Community Guidance \& Research, 24(3), 243-252.

[5] Colbeck et al (2006), The Avoidance of Bias against Caregiving the Case of Academic Faculty. American Behavioral Scientist. Vol. 49, No. 9, pp. 1222-1247.
[6] Comish, R., Swindle, B. (1994), Managing stress in the workplace, National Public Accountant, 39(9): 24-28.

[7] Cox et al (1978), Stress and Wellbeing in School Teachers. Psychological Response to Occupational Stress. Conference conducted at the meeting of the Ergonomics Society, University of Nottingham, Nottingham.

[8] Duxbury, Lyons, \& Higgins (2001), Work Life Balance in the New Millennium: Where are we? Where we need to go? CPNR Discussion paper no. W/12 October. www.cprn.org/documents/7314_en.pdf.

[9] Grecu, A., Brate, A. T., Bucuţă, M., Milcu, M., \& CernuşcăMiţariu, M. (2014). The role of individual differences as predictors in the process of occupational stress for Romanian teachers. European Journal of Science and Theology, 10, No. $3,179-184$.

[10] Hagen R (2002), Globalization, University Transformation and Economic Regeneration: A UK Case study of Public/Private Sector Partnership, International Journal of Public Sector Management, Vol. 15, pp. 204-218 http://www.elixirpublishers.com/articles/1350731463 43\%20( 2012)\%206913-6920.pdf.

[11] Kyriacou, C. (1980). Coping Actions and Occupational Stress among School Teachers. Research in Education, pp. 57-61.

[12] Leka, S., Griffiths, A. \& Cox, T (2004), Work Organization \& Stress, Systematic Problem Approaches for Employers, Managers and Trade Union Representatives. http://www.who.int/occupational_health/publications/pwh3rev .pdf.

[13] Mani V. Work Life Balance and Women Professionals. Global Journal of Management and Business Research Interdisciplinary 2013; 13(5): 2013.

[14] Mc Auley F et al (2003), Modelling the Relationship between Work-Life Balance and Organizational Outcomes. Paper presented at the Annual Conference of the Society for Industrial Organizational Psychology. Orlando, April 12, 2003, $1-26$.

[15] O' Laughlin \& Bischoff (2005). Balancing Parenthood and Academia: Work/Family Stress as Influenced By Gender and Tenure Status. Journal of Family Issues, Vol.26 No. (1), pp 79-106. doi: 10.1177/0192513X04265942.

[16] Peeters, M. C. W., Montgemery, J. J., Bakker, A.B. \& Schaufeli, W.B. (2005). Balancing work and home: How job and home demands are related to burn out. International Journal of Stress Management, 12, 43-61.

[17] Poggesi, S., Mari, M., \& De Vita, L. (2015). Family and worklife balance mechanisms: What is their impact on the performance of italian female service firms?. International Journal of Entrepreneurship and Innovation, 16, 43-53.

[18] Raza A (2012), Relationship between Occupational Stress and Job Satisfaction of Faculty: The Case of Universities of Punjab, Elixir International Journal.

[19] Repetti, R. L. (1992), Social Withdrawal as a Short-Term Coping Response to Daily Stressors. In H.S. Friedman: Hostility, Coping And Health. Washington D.C. American Psychological Association. pp. 151-165.

[20] Repetti, R. L. \& Wood (1997), The Effect of Daily Stress at Work on Mothers' Interaction With Pre - Schoolers., Journal of Family Psychology, Vol. 11, pp. 90-108. 
[21] Ross, S. D. \& Vasantha, S. (2014). A Conceptual Study on Impact of Stress on Work-Life Balance. Sai Om Journal of Commerce \& Management, 1(2), February, 1.
[22] Rout, U., Lewis, S., \& Kagan, C. (1999). Work and family roles: Indian career women, in India and the West. Indian Journal of Gender Studies, 6, 91-108. 